\title{
KRITIK IDEOLOGIS TERHADAP DASAR KEFILSAFATAN ASAS LEGALITAS DALAM HUKUM PIDANA*
}

\author{
Deni SB Yuherawan \\ E-mail: deniyuherawan@yahoo.co.id
}

\begin{abstract}
The essence of legality principle is "None is punishable for doing something unless it is forbidden by law established prior to the action". Consequently, actor of wrongdoing will not be criminally prosecuted unless penal statutes prohibit what he or she has done. The purpose of this article is to criticize the basic philosophy of legality principle. The point of departure of the critique is ontological basis of legality principle; subsequently, it goes to axiological basis of the principle. By ideological critique, it is to open up to view and at the same time criticize the basic substance and value of legality principle. In addition, this article also reexamines the legality principle. It is found that from both ontological and axiological bases, legality principle has shortcoming in that it relies upon statute rather than the substance of the conduct that may harm another. This article recommends that another more comprehensive principle be introduced, in which 'any crime should be punished if it contradicts criminal law' or nullum crimen (delictum) nulla poena sine próvia iure poenali (No offense, no punishment without criminal law previously exists).
\end{abstract}

Key words: Ideological Critique, ontological and axiological bases, and sine právia iure

\begin{abstract}
Abstrak
Esensi dari asas legalitas adalah seseorang tidak akan dipidana selama perbuatannya tidak dilarang oleh undang-undang pidana yang ada terlebih dahulu. Konsekuensinya, pelaku atau suatu perbuatan tidak akan dituntut kecuali undang-undang pidana melarangnya. Tujuan artikel ini mengkritsi dasar kefilsafatan asas legalitas. Sasaran utama kritik adalah landasan ontologis, kemudian landasan aksiologis asas legalitas. Dengan kritik ideologis, kritik tersebut untuk membuka dan mengangkat ke permukaan, sekaligus mengkritisi substansi dasar dan nilai dari asas legalitas. Selain itu, artikel ini juga melakukan pengujian kembali terhadap Asas legalitas. Dari landasan ontologis dan aksiologis, asas legalitas lebih mengutamakan keberadaan undang-undang pidana dibandingkan substansi tindakan yang mungkin merugikan pihak lain. Artikel ini merekomendasikan perlunya direkomendasikan asas lain yang lebih komprehensif, yaitu: "setiap kejahatan harus dipidana jika bertentangan dengan hukum pidana" atau dirumuskan dalam adagium: nullum crimen (delictum) nulla poena sine právia iure poenali.
\end{abstract}

Kata kunci: Kritik ideologis, landasan ontologis dan aksiologis, sine právia iure

\section{Pendahuluan}

Asas legalitas dalam hukum pidana dirumuskan dalam beberapa versi adagium, seperti nullum delictum nulla poena sine praevea lege poenali (tiada delik, tiada pidana, tanpa undang-undang pidana terlebih pidana, tanpa un-

\footnotetext{
- Artikel ini merupakan hasil penelitian Hibah Penelitian Mahasiswa Program Doktor yang dibiayai oleh Direktorat J enderal Pendidikan Tinggi, Departemen Pendidikan Nasional, dengan Surat Keputusan Rektor Universitas Airlangga Nomor: 55/ H3/ KR/2011, tanggal 29 April 2011 dan Surat Perjanjian Pelaksanaan Hibah Penelitian Mahasiswa Program Doktor Program Pascasarjana Universitas Airlangga T.A 2011 Nomor: 76/ H3.8/ KEU/2011, tanggal $30 \mathrm{~J}$ uni 2011
}

dang-undang pidana terlebih dahulu) atau nullum delictum nulla poena sine praevea lege (tiada delik, tiada pidana, tanpa undang-undang terlebih dahulu), atau nullum crimen nulla poena sine praevea lege (tiada kejahatan, tiada pidana, tanpa undang-undang terlebih dahulu).

Suatu perbuatan tidak dapat dikualifikasikan sebagai perbuatan pidana jika tidak dinyatakan sebagai perbuatan pidana oleh undang-undang pidana. Perbuatan pidana yang di larang oleh undang-undang pidana dikenal sebagai mala prohibita. Mala prohibita merupa- 
kan perbuatan perbuatan yang strafbaar (dapat dipidana).

Perbuatan pidana yang belum atau tidak dilarang oleh undang-undang pidana dikenal sebagai crimina extra ordinaria. ${ }^{1}$ Terhadap crimina extra ordinaria tidak dapat dilakukan penuntutan, karena belum dinyatakan sebagai mala prohibita, walaupun menimbulkan kerugian yang luar biasa bagi korban dan/atau masyarakat. Di antara crimina extra ordinaria tersebut terdapat perbuatan yang sangat terkenal yaitu crimina stellionatus (yang artinya: perbuatan jahat atau durjana). ${ }^{2}$ Crimina extra ordinaria merupakan perbuatan yang strafwaardig (patut dipidana) tetapi bukan strafbaar, karena tidak dilarang oleh undang-undang pidana.

Para ahli hukum pidana, pada umumnya sepakat dengan adanya 3 (tiga) makna asas legalitas, yaitu: ${ }^{3}$ pertama, tidak ada perbuatan yang dilarang dan diancam dengan pidana kalau hal itu belum dinyatakan terlebih dahulu dalam suatu aturan undang-undang; kedua, untuk menentukan adanya perbuatan pidana tidak boleh digunakan analogi (kiyas); dan ketiga, aturanaturan hukum pidana tidak berlaku surut.

Tiga makna tersebut memberikan beberapa implikasi. Pertama, larangan menggunakan analogi (prinsip non-analogi), dan kedua, keharusan menggunakan undang-undang pidana yang berlaku pada saat perbuatan dilakukan (lex temporis delicti atau existing criminal laws). Dilarang memberlakukan undang-undang pidana secara retroaktif (prinsip non-retroaktif). Implikasi tersebut merupakan konsekuensi logis dari ide dasar (basic ideas) asas legalitas, yaitu melindungi individu dengan cara membatasi dari kekuasaan penguasa (termasuk kewenangan hakim), yang mana pembatasan ini menggunakan instrumen undang-undang pidana.

Ide dasar di atas, secara substansial berimplikasi pada fungsi asas legalitas. Asas legalitas hanya melaksanakan 2 (dua) fungsi, yaitu fungsi perlindungan, melindungi warga negara dari kesewenang-wenangan kekuasaan pe-

\footnotetext{
Moeljatno 2000, Asas-Asas Hukum Pidana, Jakarta: Rineka Cipta, hlm. 24

Ibid.

lbid., hlm. 25
}

nguasa dan/atau kewenangan hakim dan fungsi pembatasan, membatasi kekuasaan penguasa dan/atau kewenangan hakim. Fungsi perlindungan ternyata hanya diberikan kepada para pelaku. Pelaku tidak akan dituntut selama perbuatan mereka tidak dilarang oleh undang-undang pidana, walaupun perbuatan tersebut menimbulkan kerugian yang luar biasa bagi korban dan/atau masyarakat. Fungsi pembatasan juga hanya untuk kepentingan pelaku, karena pemerintah tidak boleh menuntut seseorang yang perbuatannya tidak dilarang oleh undang-undang pidana, walaupun perbuatan tersebut menimbulkan kerugian luar biasa bagi korban dan/ atau masyarakat.

Asas legalitas sama sekali tidak melakukan fungsi perlindungan terhadap korban dan/ atau masyarakat. Ketiadaan fungsi perlindungan terhadap korban dan/ atau masyarakat merupakan kelemahan mendasar sekaligus keterbatasan daya berlaku asas legalitas. Asas legalitas sama sekali tidak berdaya untuk menuntut perbuatan yang menimbulkan kerugian luar biasa bagi individu dan/atau masyarakat, hanya karena perbuatan tersebut tidak dilarang oleh undang-undang pidana.

Kelemahan dan keterbatasan asas legalitas telah menimbulkan berbagai penerobosan terhadapnya, baik pada tataran aturan hukum maupun praktik hukum. Penerobosan terhadap asas legalitas pada tataran aturan hukum secara internasional adalah sebagai berikut. Pertama, European Convention for the Protection of Human Rights and Fundamental Freedoms (Konvensi Eropa untuk Perlindungan Hak-Hak Asasi Manusia dan Kebebasan-Kebebasan Fundamental). Pasal 7 Konvensi tersebut yang diberi titel No punishment without law menentukan: Satu, No one shall be held guilty of any criminal offence on account of any act or omission which did not constitute a criminal offence under national or international law at the time when it was committed. Nor shall a heavier penalty be imposed than the one that was applicable at the time the criminal offence was committed. Dua, This article shall not prejudice the trial and punishment of any person for any act or omission which, at the time when it was com- 
mitted, was criminal according to the general principles of law recognised by civilised nations.

Ayat (2) ketentuan pasal ini menentukan bahwa berlakunya pasal tersebut tidak boleh mengesampingkan peradilan dan penghukuman terhadap setiap orang yang melakukan perbuatan baik berupa kesengajaan ataupun kealpaan yang merupakan kejahatan menurut prinsipprinsip hukum umum yang diakui oleh bangsabangsa yang beradab pada saat perbuatan itu dilakukan. Ayat ini jelas telah menegasikan keabsolutan Asas legalitas yang diatur dalam Pasal 7 ayat (1) nya. Tiga, United Nations International Covenant on Civil and Political Rights/ICCPR (Konvenan Internasional tentang Hak-Hak Sipil dan Politik), tahun 1966. Pasal 15 Kovenan ini menentukan: (1) No one shall be held guilty of any criminal offence on account of any act or omission which did not constitute a criminal offence, under national or international law, at the time when it was committed. Nor shall a heavier penalty be imposed than the one that was applicable at the time when the criminal offence was committed. If, subsequently to the commission of the offence, provision is made by law for the imposition of a lighter penalty, the offender shall benefit thereby. (2) Nothing in this article shall prejudice the trial and punishment of any person for any act or omission which, at the time when it was committed, was criminal according to the general principles of law recognized by the community of nations. Ayat (2) pasal tersebut juga menegasikan keabsolutan Asas legalitas yang diatur dalam ayat (1), bahwa tidak boleh mengesampingkan peradilan dan penghukuman terhadap setiap orang yang melakukan perbuatan baik berupa kesengajaan ataupun kealpaan yang merupakan kejahatan menurut prinsip-prinsip hukum umum yang diakui oleh masyarakat bangsa-bangsa.

Penerobosan terhadap asas legalitas pada tataran praktik hukum pidana di tataran internasional adalah sebagai berikut. Pertama, putusan The International Military Tribunal (IMT) in Nuremberg dan The International Military Tribunal (IMT) in Tokyo. Sebagaimana diketahui, dua pengadilan militer internasional terse- but dibentuk berdaarkan London Charter (Piagam London) untuk mengadili para pelaku kejahatan perang pada Perang Dunia II. Negara pembentuk pengadilan militer internasional telah menetapkan perbuatan para terdakwa sebagai kejahatan perang (war crime) dan kejahatan terhadap perdamaian (crimes against peace), yang sebelumnya tidak dikenal. Secara yuridis formal, war crime maupun crimes against peace tidak dikenal dalam undang-undang pidana J erman dan J epang; kedua, putusan International Criminal Tribunal for The Former Yugoslavia (ICTY), pada tahun 1993, yang dibentuk berdasarkan Resolusi Dewan Keamanan PBB No. 827, dengan tujuan for the sole purpose of prosecuting persons responsible for serious violations of international humanitarian law committed in the territory of the former Yugoslavia". Serta putusan International Criminal Tribunal for Rwanda (ICTR) pada tahun 1994, yang dibentuk ber-dasarkan Resolusi Dewan Keamanan PBB No. 995. Kedua Pengadilan Kriminal Internasional tersebut memberlakukan undang-undang pidana secara retroaktif.

Mencermati semua penerobosan terhadap Asas Legalitas di dunia internasional, baik pada tataran aturan hukum maupun praktik hukum pidana, dapat dikatakan bahwa upaya-upaya tersebut merupakan representasi dari semua upaya yang sudah lama dilakukan pada abad XX untuk mengoreksi dan mengkritik keabsolutan asas legalitas. Namun demikian, semua upaya tersebut masih di-dasarkan pada pemikiran, bahwa asas legalitas masih tetap dianggap sebagai asas yang harus dijunjung tinggi, tetapi atas nama keadilan dapat diterobos. Implikasinya, walaupun telah terjadi penerobosan-penerobosan terhadapnya, tetapi masih belum menggoyahkan derajad keasasan Asas legalitas.

Belum tergoyahkannya derajad ke-asasan asas legalitas merupakan konsekuensi logis dari keterbatasan daya jangkau dari segala koreksi atau kritik yang telah dilakukan. Keterbatasan tersebut disebabkan, karena seluruh koreksi atau kritik yang telah dilakukan: a) sama sekali tidak menyentuh dasar kefilsafatan (landasan ontologis dan aksiologis) asas legalitas; b) dilakukan dari titik anjak secara eksternal (exter- 
nal point of view), yaitu mengoreksi dan mengkritik dengan menggunakan berbagai macam konsep di luar diri Asas legalitas, seperti klausula: war crimes; crimes against peace; crimes against humanity; gross violation of human rights (pelanggaran berat terhadap hak-hak asasi manusia); untuk dan atas nama kea-dilan; perlunya keseimbangan kepentingan korban dan pelaku; bertentangan dengan hukum yang hidup dalam masyarakat; atau pun demi the general principles of law recognized by the civilized nations or community of nations (prinsip-prinsip hukum umum yang diakui oleh bangsa-bangsa beradab atau masyarakat bangsa-bangsa). Selama koreksi atau kritik tidak ditujukan langsung kepada landasan ontologis dan akiologis asas legalitas, serta tidak dilakukan dari titik anjak secara internal (internal point of view), selama itu pula derajat keasasan asas legalitas tidak akan tergoyahkan.

Kerangka pikir untuk melakukan kritik terhadap dasar kefilsafatan asas legalitas adalah ideological critique (saya terjemahkan menjadi kritik ideologis), yaitu upaya untuk menampilkan ke permukaan pemikiran filsafat hukum yang menjadi ide dasar (basic ideas) asas legalitas, yang mana ide dasar ini terkulminasi menjadi landasan ontologis dan aksiologis asas legalitas. Upaya lebih lanjut dari kritik tersebut adalah melakukan re-eksaminasi (pengujian kembali) terhadap Asas legalitas.

Berdasarkan uraian latar belakang masalah, rumusan isu hukum yang akan dibahas pada artikel ini adalah: Pertama, mengenai alasanalasan perlunya dilakukan kritik ideologis terhadap dasar kefilsafatan asas legalitas; dan kedua, mengenai keberadaan rumusan asas lain yang yang secara hakikat lebih komprehensif daripada asas legalitas.

\section{Pembahasan}

\section{Keterbatasan-Keterbatasan Asas legalitas}

Secara substansial asas legalitas mempunyai beberapa keterbatasan. Pertama, asas legalitas hanya dapat bermakna jika ditopang oleh undang-undang pidana yang yang baik (good criminal laws), yang merupakan perwujudan kemampuan intelektual rasio, rasa ke- adilan, volonte generale (kehendak umum) dan d'interet commun (kepentingan umum). Sebaliknya, asas legalitas tidak akan bermakna jika ditopang oleh undang-undang pidana yang tidak baik (bad criminal laws), yang merupakan perwujudan kehendak dan perintah penguasa, serta perwujudan kepentingan politik penguasa (melindungi dan mempertahankan kekuasaan). Kedua, asas legalitas tidak memiliki daya jangkau untuk menuntut crimina extra ordinaria, walaupun perbuatan-perbuatan tersebut menimbulkan kerugian luar biasa bagi korban dan/ atau masyarakat. Ketiga, dengan keterbatasan daya jangkau terhadap crimina extra ordinaria, asas legalitas tidak melakukan fungsi perlindungan terhadap kepentingan korban dan/atau masyarakat yang dikorbankan demi kepentingan pelaku.

Asas legalitas dimaksudkan untuk melindungi kepentingan hak-hak warga negara dari pendefinisian perbuatan pidana yang dilakukan secara sewenang-wenang. Untuk mencegah pendefinisian yang sewenang-wenang ini, maka pendefinsian harus dilakukan dengan undangundang pidana. Pendefinisian perbuatan pidana dengan undang-undang mempunyai makna ganda. Pertama, tidak ada suatu penuntutan jika suatu perbuatan tidak dinyatakan sebagai mala prohibita ini berarti crimina extra ordinaria tidak akan dituntut, dan kedua, harus dilakukan penuntutan terhadap mala prohibita, karena warga negara dianggap tahu dan mau menerima resiko dari perbuatan yang dilakukan. Asas legalitas hanya berorientasi kepada hak-hak dan kepentingan pelaku (offender oriented). Pelaku tidak akan dituntut jika perbuatannya bukan merupakan mala prohibita. Secara aksiologis, Asas legalitas hanya memberikan nilai manfaat kepada pelaku.

\section{Re-eksaminasi terhadap Asas legalitas}

Re-eksaminasi terhadap asas legalitas menggunakan dua gagasan, yaitu: nullum crimen sine poena dan The revival of natural law (kebangkitan kembali hukum alam). Segala keterbatasan asas legalitas, disebabkan bangunan Asas legalitas beralaskan pondasi nullum crimen sine lege (tiada kejahatan tanpa undang-un- 
dang) serta nullum crimen sine poena legali (tiada kejahatan, tanpa pidana menurut undangundang). Pondasi ini hanya membangun relasi perbuatan pidana - undang-undang pidana dan penguasa - pelaku, dengan memberikan nilai manfaat kepada pelaku perbuatan.

Gagasan nullum crimen sine lege dan nullum crimen sine poena legali merupakan resultan pemikiran filsafati J aman Rasionalisme, terutama pada Abad XVIII (J aman Aufklarung atau Enlightenment) yang dimotori J ohn Locke, Montesquieu, Rousseau, dan Beccaria. Kemudian gagasan ini semakin kokoh dengan munculnya positivisme hukum pada Abad XIX, serta neokantianisme dan neopositivisme hukum pada Abad XX. Dalam perspektif yang lain yakni untuk kepentingan korban dan atau masyarakat (victims or/and society oriented), terhadap semua kejahatan yang merugikan korban dan/ atau masyarakat harus dituntut dan dipidana. Peniadaan penuntutan dan pemidanaan terhadap suatu perbuatan hanyalah alasan pembenar dan alasan pemaaf. Orientasi terhadap kepentingan korban dan/atau masyarakat harus dibangun di atas pondasi nullum crimen sine poena.

Pondasi nullum crimen sine poena akan membentuk hukum pidana dan peradilan pidana yang akan menuntut semua perbuatan pidana, baik mala prohobita maupun crimina extra ordinaria, dengan alasan semua perbuatan pidana akan selalu menimbulkan kerugian bagi korban dan/ atau masyarakat. Berdasarkan pondasi tersebut, menuntut dan memidana pelaku merupakan keharusan, agar pelaku bertanggungjawab atas segala perbuatan yang dilakukan.

Berdasarkan sejarah hukum, gagasan tentang nullum crimen sine poena sudah ada sejak J aman Yunani dan Romawi. Kemudian, gagasan ini juga berkembang pada Jaman Pertengahan maupun Jaman Modern. Para pemikir pada masing-masing jaman ada yang menyampaikan gagasan nullum crimen sine poena secara tersurat dalam pokok-pokok pikirannya, ada juga yang secara tersirat. Satu hal yang sudah pasti, tidak ada satu pun pemikir yang berkeinginan bahwa seorang pelaku kejahatan dibebaskan tanpa pidana.
Berkaitan dengan keharusan menghukum orang yang melakukan pelanggaran hukum, Plato berpendapat: ${ }^{4}$

"Orang-orang yang melanggar hukum harus dihukum, tetapi hukuman tidak pernah boleh dipandang sebagai pembalasan terhadap ketidakadilan. Pelanggaran merupakan penyakit pada bagian intelektual manusia (logistikon). Cara menyembuhkan si sakit adalah melalui hukuman, Hukuman bertujuan memperbaiki sikap moral si pelanggar. Tetapi seandainya penyakit itu tidak disembuhkan, orang itu harus dibunuh"

Bagi Plato bahwa setiap pelanggaran hukum (baca:kejahatan/ perbuatan pidana) harus dipidana, tetapi pemidanaan tersebut tidak boleh dilakukan sebagai balas dendam, namun dalam rangka rehabilitasi moral pelaku. Gagasan Plato pada hakikatnya adalah prinsip keharusan memidana kejahatan.

Pokok-pokok pikiran Aristoteles adalah sebagai berikut: ${ }^{5}$

"Tentang perbuatan pidana dan pemidanaan menggunakan prinsip geometris dan aritmetika. Penggunaan prinsip geometris didalilkan: seorang melakukan perbuatan pidana, harus dihukum sesuai dengan apa yang terjadi, dengan memperhatikan kedudukan yang dirugikan, sedang penggunaan prinsip aritmetika didalilkan: seorang melakukan perbuatan pidana, harus dihukum sesuai dengan apa yang terjadi, dengan tidak mengindahkan kedudukan kedua pihak.

Aristoteles menegaskan, bahwa merupakan suatu keadilan jika warga negara patuh kepada hukum tertulis maupun tidak tertulis. Dan bagi warga negara yang melanggar hukum (baca: melakukan kejahatan) harus dipidana. UIpianus seorang filsuf jaman Romawi menyusun dalil prinsipiil, yaitu honeste vivere, alterum non laedere, suum cuique tribuere (hidup secara terhormat, tidak mengganggu orang lain, memberikan kepada setiap orang apa yang

\footnotetext{
Theo Huijbers, 1982, Filsafat Hukum Dalam Lintasan Sejarah, J ogyakarta: Penerbit Kanisius, hlm. 24

5 Ibid., hlm. 28-30
} 
menjadi bagiannya) ${ }^{6}$. Secara esensial, prinsip alterum non laedere merupakan larangan untuk mengganggu orang lain. Prinsip ini mengharuskan setiap orang mempertanggungjawabkan segala perbuatannya, karena menimbulkan kerugian bagi orang lain.

Gagasan nullum crimen sine poena juga berkembang pada abad-abad sesudahnya, yakni Jaman Pertengahan, yang berlangsung pada Abad V sampai XV. Paling tidak gagasan ini dapat disarikan dari pemikiran Augustinus (354430 M) dan Thomas Aqui-nas/Thomas Aquino (1225-1275 M). Agustinus berpendapat bahwa: ${ }^{7}$

"Hukum abadi yang terletak dalam Budi Allah, terdapat juga dalam jiwa manusia, yang dinamakan lex naturalis (hukum alam). Partisipasi lex aeterna terhadap lex naturalis terdapat pada rasa keadilan, yak-ni suatu sikap jiwa untuk memberikan kepada setiap orang apa yang patut baginya, dengan mengindahkan juga tuntutan-tuntutan kepentingan umum. Prinsip tertinggi dalam hukum alam adalah ne aliquid faciat quisque alteri, quod pati ipse non vult (jangan berbuat kepada orang lain, apa yang engkau tidak ingin orang lain berbuat kepadamu)"

Agustinius menegaskan arti penting konsep keadilan yang merupakan ekspresi sikap jiwa untuk memenuhi tuntutan-tuntutan pribadi dengan mengindahkan kepentingan umum dan konsep ne aliquid faciat quisque alteri, quod pati ipse non vult (jangan berbuat kepada orang lain, apa yang engkau tidak ingin orang lain berbuat kepadamu). Dia mengingatkan bahwa kepentingan umum mempunyai kedudukan yang lebih penting dari kepentingan pribadi. Dalam kehidupan bermasyarakat, individu-individu mempunyai hak untuk memperjuangkan dan memenuhi kebutuhan hidupnya, tetapi dalam perjuangan dan pemenuhan hak tersebut tidak boleh merugikan kepentingan orang lain atau kepentingan umum. Dalam penegakan hukum meskipun sama-sama mengaku dirinya sebagai negara hukum (Rechtstaat) sebenarnya di manapun di dunia ini tidak ada standar yang ab-

6 Satjipto Rahardjo, 2000, IImu Hukum, Bandung: Citra Aditya Bakti, hlm. 258

7 Theo Huijbers, op.cit., hlm. 38 solut. ${ }^{8}$ Kepentingan umum merupakan batu uji untuk memvalidasi eksistensi kepentingan individu. Signifikansi kepentingan umum diwujudkan dalam prinsip hukum tertinggi ne aliquid faciat quisque alteri, quod pati ipse non vult. Prinsip ini mengajarkan agar kita tidak mengganggu atau merugikan orang lain, karena pada hakikatnnya kita juga tidak mau diganggu atau dirugikan oleh orang lain.

Berdasarkan perspektif hukum pidana, prinsip tersebut pada hakikatnya mengajarkan bahwa seseorang harus bertanggungj awab secara pidana, jika dia melakukan kejahatan (yang sudah pasti merugikan orang lain). Keharusan memidana kejahatan dilakukan dalam rangka melindungi kepentingan korban dan/atau masyarakat, yang memiliki gradasi lebih tinggi dari kepentingan individu (pelaku). Sedang pokokpokok pikiran Thomas Aquinas adalah sebagai berikut. ${ }^{9}$ Pertama, aturan alam harus diresapi dan diteruskan dalam manusia sendiri, yakni dalam kemampuannya untuk membedakan apa yang baik dan apa yang jahat. Semua orang seharusnya mengetahui tentang dasar hidup moral, yakni: bonum est faciendum, malum est vitandum (yang baik harus dilakukan, yang jahat harus dihindarkan), yang baik adalah apa yang sesuai dengan kecenderungan aturan alam, dan yang jahat adalah apa yang sebaliknya; kedua, hukum alam yang yang dicerna atau diresepsi oleh akal budi dibagi menjadi 2 (dua) golongan, yaitu hukum alam primer dan hukum alam sekunder. Hukum alam primer dirumuskan ke dalam norma-norma, yang karena bersifat umum, berlaku bagi semua manusia (principia prima communia), seperti halnya 2 (dua) norma yang juga menjadi pegangan aliran Stoa, yaitu: unicuique suum tribuere (berikan kepada setiap orang apa yang telah menjadi haknya) dan neminem laedere (jangan merugikan seseorang); dan ketiga, negara adalah masyarakat yang sempurna (societas perfecta). Dalam mayarakat ini, manusia mendapat perlengkapannya sebagai makhluk sosial. Orang yang tidak memperhatikan kepentingan umum, tidak berlaku seba-

\footnotetext{
Satjipto Rahardjo, op.cit

9 Theo Huij bers, op.cit, hlm. 40-43
} 
gai makhluk sosial dan tidak sampai kepada kesempurnaan hidup.

Thomas Aquinas mengajarkan tentang aspek imperatif suatu kehidupan sosial. Kehidupan masyarakat harus dilandasi oleh dasar hidup moral, yakni bonum est faciendum, malum est vitandum. Tatanan kehidupan masyarakat akan berlangsung aman dan tenteram jika masingmasing melakukan hal-hal yang baik, dan terutama menghindari perbuatan yang jahat.

Keharusan melakukan perbuatan-perbuatan yang baik dan menghindari perbuatan-perbuatan yang jahat, oleh Thomas Aquinas diwujudkan dalam prinsip hubungan antar sesama yakni neminem laedere (jangan merugikan seseorang). Prinsip ini dilakukan dalam kerangka kepentingan umum, dimana setiap warga negara dalam perbuatannya selalu dibatasi dan/atau untuk mewujudkan kepentingan umum. Setiap warga negara yang menimbulkan kerugian bagi seseorang apalagi kepentingan umum, harus mempertanggungjawabkan segala perbuatannya. Jika kerugian tersebut disebabkan karena suatu kejahatan, maka terhadap pelaku harus dimintakan pertanggungj awaban pidana.

Gagasan nullum crimen sine poena juga terdapat pada Jaman Modern (Abad XV sampai Abad XIX). Pemikir Jaman Renaissance yaitu Hugo de Groot atau Grotius menge-mukakan pendapatnya bahwa: ${ }^{10}$

Prinsip rasional yang pertama dari hukum rasional (Vernunftrecht) adalah setiap manusia mempunyai kecenderungan untuk hidup bersama orang lain secara damai. Dari prinsip dasar tersebut dialirkan 4 (empat) prinsip lain yang harus ditaati agar hidup bersama secara damai dapat berlangsung, yaitu: (a) Prinsip kupunya dan kau punya, (b) Prinsip kesetiaan pada janji, (c) Prinsip ganti rugi, yakni jika kerugian tersebut disebabkan karena orang lain, dan (d) Prinsip penghukuman terhadap pelanggaran hukum alam dan hukumhukum lain.

Prinsip ganti rugi dan perlunya penghukuman yang digagas oleh Hugo de Groot merupakan konsekuensi logis dari keharusan adanya pertanggungjawaban dari siapa saja yang me-

$10 \quad$ lbid., hlm. 59-62 nimbulkan kerugian dan/atau melanggar hukum (melakukan kejahatan). Keseluruhan gagasan di atas, pada hakikatnya merupakan nullum crimen sine poena. Hanya saja, gagasan tersebut mengalami perubahan radikal pada Abad XVIII. Dengan diresapi pemikiran J ohn Locke, Mostesquieu, Rousseau dan Beccaria, gagasan nullum crimen sine poena berubah menjadi nullum crimen sine lege dan nullum crimen sine poena legali, sebagaimana terdapat dalam Pasal 8 Declaration des droits de L'homme et du citoyen (1789) yang menentukan La Loi ne doit établir que des peines strictement et évidemment nécessaires, et nul ne peut être puni qu'en vertu d'une Loi établie et promulguée antérieurement au délit, et légalement appliquée (artinya: keharusan membuat undang-undang secara tegas dan per-buatan hanya dapat dituntut atas dasar undang-undang yang berlaku). Ketentuan tersebut kemudian diatur dalam Pasal 4 Code Penal Perancis yang menentukan: Nulle contravention, nul delit, nul crime ne peuvent etre punis de peinesqui n'etaient pas prononcees par la loi avant qu'ils fussent commis (artinya: tidak bertentangan dengan ketentuan yang ada, tiada delik, tiada kejahatan jika tidak ada ancaman pidana yang dinyatakan dalam undangundang terlebih dahulu). Inilah yang kemudian dikenal dengan nama asas legalitas, yang dicantumkan dalam Kitab Undang-Undang Hukum Pidana di banyak negara, serta ditasbihkan sebagai konsep final dan kebenaran absolut.

Asas legalitas sebagai konsep final dan kebenaran absolut semakin diperkokoh dan ditumbuhkembangkan oleh aliran positivisme hukum, karena positivisme hukum mengajarkan beberapa hal. Pertama, tidak ada hukum selain hukum positif, yakni hukum ditetapkan oleh penguasa; kedua, tidak ada hukum selain hukum tertulis (written law), sehingga hukum yang tidak tertulis tidak dapat diklasifikaikan sebagai hukum; ketiga, tidak ada hukum selain undangundang (statutory), sehingga yang berlaku adalah hukum undang-undang (statute law). Di luar undang-undang, tidak ada lagi hukum; keempat, hanya berkutat dengan persoalan aspek formal hukum daripada substansi hukum. Dengan kata lain, lebih mementingkan bentuk 
(formalitas) hukum dibandingkan materi (substansi); dan kelima, hukum harus dipisahkan dari persoalan-persoalan moral dan keadilan.

Asas legalitas dan positivisme hukum merupakan 2 (dua) gagasan yang saling menguatkan, karena masing-masing mengakui undangundang pidana sebagai satu-satunya pilar hukum dan sistem peradilan pidana. Secara praksis, positivisme hukum menerima asas legalitas sebagai konsep final dan kebenarann absolut yang tidak perlu diperdebatkan lagi. Bahkan dalam rentang waktu yang lama, positivisme hukum telah menjadi pengawal terdepan untuk menolak segala penyimpangan terhadap asas legalitas.

Kemudian, dalam kenyataan, positivisme hukum hanya mampu bertahan untuk suatu keadaan yang stabil. Tetapi mengalami kegagalan manakala terjadi kegoncangan di banyak negara. Positivisme hukum telah gagal, karena tidak mampu memberikan tuntunan di tengahtengah gugatan terhadap kepercayaan sosial dan moral saat itu. Juga gagal, karena tidak mampu memberikan pertolongan atas terjadinya penyalahgunaan kekuasaan dan kemerdekaan yang terjadi. ${ }^{11}$

Sebenarnya telah dilakukan otokritik terhadap positivisme hukum oleh para pemikir neokantianisme dan neopositivisme hukum. Mereka menyadari tentang kelemahan-kelemahan positivisme hukum yang hanya mengakui aspek formal hukum dengan mengabaikan aspek substansial, yakni mengeluarkan moralitas, terutama nilai-nilai keadilan dan kebenaran dari substansi hukum. Sebagai penganut neokantianisme, Rudolf Stamler dan Gustav Radbruch telah melakukan oto-kritik. Sebagaimana dikemukakan oleh Theo Huij bers, bahwa:

"Sebenarnya Stammler sendiri merasa kesulitan untuk mempertahankan pengertian hukum yang hanya memperhatikan sisi logis-formalnya saja, tanpa memperhatikan prinsip-prinsip materiil yang menentukan isi hukum. Oleh karena itu, Stammler mengakui adanya suatu hukum yang diisi, di samping hukum positif yang lepas dari isinya. Hukum yang diisi itu adalah hukum yang adil. Kiranya hukum ini dapat

11 Satjipto Rahardjo, op.cit., hlm. 262 disamakan dengan Hukum Alam. Ternyata dengan pernyataan terakhir ini, Stammler sudah melepaskan positivisme hukum yang dianut-nya" ${ }^{12}$

Rudolf Stamler, meskipun menganut positivisme hukum, ternyata mengakui keberadaan hukum yang diisi yang dianggap sebagai hukum yang adil. Namun demikian, meskipun mengakui keberadaan hukum yang diisi tersebut, masih belum membuat Stamler melepaskan diri dari pemikiran positivisme hukum. Gustav Radbruch mengemukakan gagasan, bahwa:

Oleh karena kepastian hukum harus dijaga demi keamanan dalam negara, maka hukum positif harus selalu ditaati, meskipun isinya kurang adil ataupun kurang sesuai dengan tujuan hukum. Tetapi terdapat perkecualian, yakni bilamana pertentangan isi hukum tata hukum dan keadilan menjadi begitu besar, sehingga tata hukum itu nampak tidak adil. Pada saat itu, tata hukum boleh dilepaskan. ${ }^{13}$

Gustav Radbruch dalam Five Minutes of Legal Philosophy (1945), menegaskan: ${ }^{14}$

“... In the end, the positivistic theory equates law with power; there is law only where there is power... And of course laws have value in and of themselves, even bad laws: the value, namely, of securing law against uncertainty. There can be laws that are so unjust and so socially harmful that validity, indeed legal character itself, must be dinied them... There are principles of law, therefore, that are weightier than any legal enactment, so that a law in conflict with them is devoid of validity. These principles are known as natural law or the law of reason"

Awalnya, Gustav Radbruch menegaskan hukum tetaplah hukum bagaimana pun buruknya. Nilai esensial hukum adalah kepastian hukum. Tetapi pada akhirnya, dia mengakui adanya prinsip-prinsip hukum yang lebih tinggi tingkatannya dari hukum positif yaitu hukum alam.

\footnotetext{
Theo Huij bers, op.cit., hlm. 156

3 Ibid., hlm. 166

14 Litschewski Bonnie Paulson, dan Stanley L. Paulson, "Five Minutes of Legal Philosophy (1945): Gustav Radbruch", Oxford J ournal of Legal Studies, Vol 26, No. 1, 2006, hlm. 13-15
} 
Bahkan ditegaskan, jika hukum positif bertentangan dengan hukum alam, makan hukum positif kehilangan vali-ditasnya.

Otokritik juga dikemukakan oleh para penganut Neopositivisme hukum. Sebagai penganut Neopositivisme hukum, H.L.A. Hart menyadari bahwa aspek substansial hukum bukan hanya perintah, tetapi ada aspek internal lain yakni prinsip-prinsip moral dan ke-nyataan-kenyataan hidup tertentu (natural facts), yang mengakibatkan munculnya kepatuhan terhadap hukum. ${ }^{15}$ Aspek internal ini diposisikan sebagai kritik normatif terhadap hukum. Julius Stone juga mengemukakan gagasan tentang keinsyafan keadilan, dimana nilai keadilan menjadi norma etis bagi hukum positif. ${ }^{16}$

Selain otokritik, kritik tajam juga dilakukan oleh tokoh-tokoh pemikir hukum alam bermaksud untuk membela keadilan sebagai unsur hakiki segala hukum. Unsur keadilan ini telah dilalaikan dalam positivisme hukum, yang tidak mengakui suatu norma etis bagi berlakunya hukum. Menurut mereka, suatu norma etis dibutuhkan untuk menjadi dasar suatu hukum yang sah, yang terletak dalam hukum alam. ${ }^{17}$ Dengan semakin mundur dan memudarnya positivisme hukum, maka hiduplah kembali hukum alam, yang dikenal dengan nama The Revival of $\mathrm{Na}$ tural Law (Kebangkitan Kembali Hukum Alam).

Menurut Allen, penggunaan istilah kebangkitan kurang tepat, karena berbeda dengan hukum alam pada abad-abad sebelumnya. hukum alam yang sekarang ini menganut konsep relativitas yang berbeda dengan konsep Hukum Alam yang terdahulu yang bersifat absolut. Satu-satunya titik yang menghubungkan antara keduanya adalah didasari oleh keinginan untuk menyatakan suatu idealisme moral. ${ }^{18}$

Francois Geny (1861-1959) sebagai penganut Neothomisme mengemukakan beberapa pokok pikirannya. ${ }^{19}$ Pertama, hukum alam merupakan prinsip-prinsip materiil hukum, yang tidak tergantung pada kemauan manusia, tetapi berasal dari alam sendiri, dan dengan demikian

\footnotetext{
Ibid., hlm. 189-190

Ibid., hlm. 192-193

lbid., hlm. 245

Satjipto Rahardjo, op.cit., hlm. 267

Theo Huij bers, op.cit., hlm. 249-251
}

sebagai dasar hukum positif; dan kedua, hukum alam hanya berhubungan dengan prinsip-prinsip tertinggi, yang tidak berubah dan selalu berlaku. Prinsip-prinsip yang berhubungan dengan kenyataan alam dan kenyataan rasional merupakan hukum alam, yang terdiri atas normanorma primer dan sekunder. Norma-norma primer hukum alam adalah: unicuique suum tribuere (berikan kepada setiap orang apa yang menjadi haknya) dan neminem laedere (jangan merugikan seseorang). Sedang norma-norma sekunder adalah semua hak fundamental manusia. Prinsip-prinsip tersebut yang berasal dari kenyataan alam dan kenyataan rasional merupakan dasar semua aturan hukum positif.

Bagi Geny, prinsip-prinsip materiil hukum adalah prinsip unicuique suum tribuere, neminem laedere, dan keseluruhan hak asasi manusia. Geny mengajarkan bahwa terdapat unsur penting dalam pengertian tentang hukum yakni prinsip-prinsip materiil, yang melebihi kehendak manusia, dan sebagai dasar hukum positif.

Pokok-pokok pikiran kebangkitan kembali hukum alam adalah sebagai berikut. Pertama, teori-teori hukum alam selalu berprinsip bahwa hukum merupakan obyek yang dwi-tunggal yaitu harmonisasi aspek substansial (nilai-nilai keadilan) dan aspek formal (bentuk tertulisnya: hukum positif/hukum tertulis). Hukum merupakan perwujudan nilai-nilai dan prinsip-prinsip keadiIan. Hukum bukan saja harus correct (tepat) dan certain (pasti) untuk mencerminkan aspek formalnya, tetapi harus just (adil) untuk mencerminkan aspek substansialnya. Kategori etis (subs-tansial) dan yuridis (formal) merupakan dua momen dari satu realitas hukum; kedua, keadilan dan kepastian merupakan dua aspek dari entitas hukum. Hukum merupakan entitas yang terdiri dari unsur keadilan dan kepastian. Tetapi mengingat bahwa keadilan merupakan norma etis dan norma kritis bagi hukum, maka keadilan mempunyai gradasi lebih tinggi dibandingkan kepastian hukum; ketiga, tujuan hukum adalah mewujudkan dan mencapai cita keadilan. Keberadaan kepastian hukum semata-mata untuk mewujudkan dan mencapai keadilan; keempat, signifikansi eksistensi nilai-nilai keadilan, teori hukum alam membuat suatu adagium: 
moral (prinsip-prinsip keadilan dan perikemanusiaan) lebih tinggi tingkatannya dari hukum positif; kelima, hukum bukan saja hukum positif/ tertulis (yang substansinya harus mencerminkan nilai-nilai keadilan), tetapi juga hukum tidak tertulis (yang merupakan perwujudan perasaan hukum atau nilai-nilai keadilan masyarakat, sebagai hukum yang hidup dalam masyarakat); keenam, hukum pada hakekatnya sarat dengan nilai-nilai keadilan. Hukum tidak saja berhubungan erat, bahkan merupakan nilai itu sendiri. Pembentukan hukum harus mampu menciptakan keadilan dalam kehidupan bermasyarakat, bukan sekedar menciptakan kepastian. Teori hukum alam selalu mempersepsikan bahwa hukum merupakan upaya etis manusia sebagai eksistensi sekaligus koeksistensi untuk mengatur kehidupan bermasyarakat secara berkeadilan. Dengan demikian, hukum positif merupakan realisasi keinsyafan manusia atas prinsip-prinsip keadilan untuk mengatur kehidupan bersama; ketujuh, teori hukum alam mengajarkan kepada kita bahwa kepentingan individu (pada saat manusia sebagai pribadi, sebagai eksistensi) harus dijunjung tinggi dan tidak dapat diganggu gugat. Namun kepentingan individu ini turun gradasinya, manakala individu yang bersangkutan meleburkan diri dalam kehidupan bersama (sebagai pribadi berubah menjadi anggota masyarakat, sebagai eksistensi berubah menjadi koeksistensi). Dalam konteks kehidupan bersama, kepentingan umum (kolektif) mempunyai derajat lebih tinggi dibandingkan kepentingan individu, suatu situasi dimana kepentingan individu dibatasi oleh kepentingan umum (kolektif).

Kebangkitan kembali hukum alam memberikan beberapa kritik tajam kepada positivisme hukum. Pertama, positivisme hukum hanya mampu menjelaskan bahan-bahan yang termasuk hukum (quid iuris?) dalam waktu dan tempat tertentu, tetapi belum dapat menjelaskan persoalan pokok yaitu apa makna hukum (quid ius?); kedua, positivisme hukum hanya mengkaji aspek formal dari hukum, sedang substansi hukum (aspek materiil) benar-benar ditinggalkan; ketiga, membedakan pengertian hukum dan ide hukum, sehingga tidak dapat lagi membedakan hukum yang adil dan yang tidak adil; keempat, secara filsafat hukum, dipahami sepenuhnya bahwa hukum harus correct (tepat) dan certain (pasti) sebagaimana tuntutan eksternal serta aspek formal dari hukum. Akan tetapi, hukum harus just (adil) sebagaimana tuntutan internal dan aspek substansial (materiil) dari hukum, di mana hukum dianggap benar-benar sebagai hukum karena sesuai dengan nilai-nilai atau prinsip-prinsip keadilan; dan kelima, hukum bukan saja richtiges recht (hukum yang pasti), melainkan juga gerechtes recht (hukum yang adil). Hal ini sesuai dengan adagium ius quia justum (hukum karena adil).

Entitas hukum tidak dapat dipisahkan dari nilai-nilai moral (nilai-nilai keadilan), bahkan moralitas digagas sebagai substansi hukum. Para pemikir hukum semakin berkeyakinan bahwa aspek suabstansial hukum adalah moralitas (nilai-nilai keadilan). Dengan demikian, secara ontologis, hukum harus bersubstansikan nilai-nilai keadilan. Dalam hal ini, Russel menegaskan, bahwa:

"historically, the standart argument from natural lawyers has been that law is an expression of practical reason and that practical reason is regulated by moral principles, so that laws that fail to incorporate a certain moral content are not genuine lawseven if they are on the books. Unjust laws are ultimately, then, perversions of practical reason. The main philosophical issue in this context concerns whether practical reason incorporates and is governed in some relevant way by morality". ${ }^{20}$

Secara histors argumen standar dari ahli hukum alam bagi Russel adalah bahwa hukum merupakan perwujudan alasan praktis yang diatur oleh prinsip-prinsip moral. Undang-undang yang gagal memasukkan prinsip-prinsip tersebut, tidak dapat dikatakan sebagai hukum yang sesungguhnya, dan hukum yang tidak adil merupakan penyimpangan dari alasan praktis dibuatnya hukum.

Kritik terhadap positivisme hukum masih saja dilakukan pada saat ini. Selain mengajukan

20 J.S. Russel, "Trial By Slogan: Natural Law anf Lex Iniusta Non Est Lex", Law and Philosophy, Vol.19, 2000, Kluwer Academic Publisher, Netherlands 
kritik, para pemikir hukum juga mengedepankan pentingnya nilai keadilan sebagai substansi hukum. Ternyata, sampai pada Abad XXI, positivisme hukum masih banyak dianut oleh para ahli hukum, sebagai mana sinyalemen Howard Bromberg, yang berpendapat: ${ }^{21}$

A central question of analytical and philosophical jurisprudence: what is positive law? Throughout his analysis, Murphy contrast positive law with two kinds of law that constitute the triad of legalconcept - natural law and customary law; kedua, Law can be identified and distinguished from other norms by a set of empirical criteria and that the content of law has no necessary connections to moral truth.

Bromberg menegaskan bahwa masih ada yang menganut positivisme hukum, yang masih mempertentangkan hukum positif dengan hukum alam dan hukum kebiasaan, yang masih berkeyakinan bahwa substansi hukum tidak harus mempunyai kaitan dengan kebenaran moral. Untuk mengkritisi pemikiran yang positivistik ini, Norman Barry mengemukakan analisisnya, bahwa "however, Dworkins make a distinction between rules and principles. Principles, unlike rules, do not apply all the time, but are called on by judges to settle hard cases. They are not expressed formally, but are immanent in the morality of community. Nevertheless, they are intrinsically a part of law". ${ }^{22}$

Norman Barry menegaskan, meskipun ada yang membedakan antara aturan hukum dan asas-asas. Asas-asas, memang tidak seperti aturan hukum yang selalu diterapkan setiap saat. Akan tetapi asas hukum sangat dibutuhkan hakim untuk menyelesaikan kasus-kasus berat. Asas-asas memang tidak dirumuskan secara tersurat dalam aturan hukum, tetapi merupakan bagian yang tidak terpisahkan dari moralitas masyarakat.

Max Leskiewicz berpendapat, "Many accounts of the relationship between law and morality (and between legal and moral respon-

21 Howard Bromberg, "The Philosophy of Positive Law: Foundations of Jurisprudence", The Review of Metaphysics, Vol 60, Mar 2007, Washington

22 Norman Barry, "Dworkin's unbounded legalism, Ideas on Liberty", Vol. 52, November 2002, Irvington-Hudson. sibility) rest on the idea of morality is a source of ultimate values whereas law is purely conventional. Adherents of view will argue that to extend that legal rules and principle of responsibility...(conceide) with morality". ${ }^{23}$ Max Leskiewicz ingin menyampaikan bahwa persoalanpersoalan hubungan antara hukum dan moralitas (pertanggungjawaban hukum dengan pertanggungj awaban moral) dengan gagasan moralitas sebagai nilai-nilai yang menentukan dalam hukum merupakan persoalan masa lalu. Pada masa mendatang perlu dikembangkan bahwa aturan hukum dan prinsip pertanggungjawaban harus dikaitkan dengan moralitas.

Andrei Marmor berpendapat, bahwa "basically, the dispute is about the conditions of legal validity. Non-positivist assert, while positivist deny, that moral considerations form an essential part of the conditions of legal validity, and conceptually so". ${ }^{24}$ Secara mendasar, perselisihan berkaitan dengan kondisi validitas hukum. Anti-positivisme menyepakati dan yang pro-positivisme menolak adanya konsep yakni pertimbangan moral merupakan bagian esensial validitas hukum.

Kemudian dinyatakan juga, bahwa

"there are three main versions of this anti-positivist stance": 1) According do (what we call) traditional natural law doctrine, the separation thesis is false because moral considerations form a necessary condition of legal validity. Unjust law (or grossly unjust law) is not law, not legally valid; 2) According to (early) Dworkin, though morality is not a necessary condition of legal validity, it is some-times sufficient condition. A norm can be a legal norm because it derives from the best moral justification of other norms (legal prin-ciples). Thus, at least in some cases, there is a concepttual connection between legal validity and morality; 3) According to 'Law's Empires' Dworkin, legal validity is always partly a matter of moral judgement,

23 Max Leskiewicz, "The Normative Ontology of The Law Peter Cane's Responsibility in Law and Morality", University of Queensland Law J ournal Vol 22, 2003, St. Lucia.

24 Andrei Marmor, "Legal Positivism: Still Descriptive and Morally Neutral", Oxford J ournal of Legal Studies, Vol 26 (No.4), 2006 
because it always a matter of interpretation what the law is, and interpretation is always partly a matter of moral/ evaluative judgement. ${ }^{25}$

Andrei Marmor menguraikan bahwa pertimbangan moral tidak dapat dilepaskan dari persoalan validitas hukum. Jika dikaitkan dengan doktrin hukum alam tradisional, maka pemisahan pertimbangan-pertimbangan moral dari validitas hukum merupakan suatu kekeliruan. Hukum yang tidak adil bukanlah hukum, dan tidak mempunyai validitas hukum. Jika dikaitkan dengan pendapat awal Dworkin, maka walaupun moralitas bukanlah bagian penting dari validitas hukum, tetapi kadang-kadang sangat dibutuhkan. Suatu norma menjadi norma hukum karena diderivasikan dari kebenaran moral norma yang lain (seperti prinsip-prinsip hukum). Paling tidak dalam beberapa kasus terdapat ikatan konseptual antara validitas hukum dan moralitas. J ika dikaitkan dengan gagasan Dworkin yang berikutnya, validitas hukum merupakan bagian dari penilaian moral, karena penafsiran tentang apakah hukum itu selalu merupakan penilaian evaluatif atau penilaian secara moral.

Danny Priel menyampaikan argumen-tasinya, bahwa ${ }^{26}$

1) I hope the arguments provided give reason for realizing, at least sometimes, moral considerations will be taken into account in determining what the law is; 2) True, claim of conceptual separation law and morality have been something of a battle cry for legal positivist for quite some time and are probably the most important aspect of the history of this idea. But, in recent years quite a few positivist have seen no conflict between their positivism and a belief in the existence of necessary connections between law and morality.

Danny Prieel pada dasarnya ingin menegaskan bahwa paling tidak suatu saat pertimbangan-pertimbangan moral akan dijadikan faktor untuk menentukan apakah sebenarnya hukum itu. Memang pemisahan secara konseptual

Ibid.

26 Danny Priel, "Trouble for Legal Positivism", Legal Theory, Sept 2006, Vo. 12, Cambridge. antara hukum dan moralitas telah mewarnai sejarah hukum, tetapi pada tahun-tahun belakangan ini, beberapa positivis telah melihat tidak ada konflik dan percaya terhadap eksistensi keharusan adanya keterkaitan antara hukum dan moralitas.

Paul J ohnson berpendapat, "The object of law is to civilize our passion for justice and so make it effective. Legal philosophers and reformer ought to concentrate on making this civilizing process work better". ${ }^{27}$ Tujuan hukum adalah untuk memasyarakatkan hasrat terhadap keadilan dan membuatnya berhasil guna. Filsuf hukum dan pereformasi hukum seharusnya berkonsentrasi agar proses memasyarakatkan keadilan bekerja dengan lebih baik.

Perdebatan tentang positivisme hukum dan hukum alam juga menarik perhatian Schauer dengan menganalisis gagasan Hart dan Fuller. Dia menyatakan:

“... I want to turn to Fullers's debate with Hart over the virtues and vices of legal positivism. I hope to show that the debate is less about whether positivism is right or normatively desirable than about the extent to which positivism is most at home with an external point of view to law that Fuller did not share, and that conversely Fuller's version of natural law is most confortable with an internal point of view to the law that many positivist di not share". ${ }^{28}$

Bagi Schauer, perdebatan tersebut tentang kebaikan dan keburukan positivisme hukum. Dan perdebatan ini karena adanya perbedaan sudut pandang. Jika positivisme hukum memahami hukum dari sudut pandang eksternal, maka hukum alam memahami hukum dari sudut pandang internal. Dengan demikian, kebenaran dan sifat normatif bagi positivisme hukum adalah aspek formal dari undang-undang, sedang kebenaran dan sifat normatif bagi hukum alam adalah aspek substansial dari undangundang.

\footnotetext{
27 Paul J ohnson, "Do we need a legal philosophy? If so, what should it be?", The Spectator Vol 284, J an 29, 2006. London

28 Frederick Schauer, "Fuller's Internal Point of View", Law and Philosohy, Vol. 13, 1994, Kluwer Academic Publisher, Netherlands
} 
Berdasarkan keseluruhan pendapat di atas, dapat disimpulkan bahwa entitas hukum tidak dapat dipisahkan dari moral (dengan keadilan dan kebenaran sebagai nilai tertinggi), bahkan moralitas digagas sebagai substansi hukum. Para pemikir hukum semakin berkeyakinan bahwa aspek substansial hukum adalah moralitas. Secara ontologis, hukum harus bersubstansikan moralitas (nilai-nilai keadilan dan kebenaran). Pokok-pokok pikiran tersebut tidak pernah berpretensi untuk menegasikan eksistensi undang-undang, selama undang-undang tersebut merupakan perwujudan sekaligus untuk mencapai cita keadilan. Nilai-nilai keadilan senantiasa akan dijadikan norma etis dan evaluatif, jika eksistensi undang-undang hanya sekedar perwujudan kehendak dan perintah penguasa, dengan mengabaikan bahkan menegasikan nilai-nilai keadilan.

Pokok-pokok pikiran kebangkitan kembali hukum alam dapat digunakan untuk melakukan reekasaminasi terhadap asas legalitas. Asas legalitas yang ditopang oleh positivisme hukum hanya mengakui undang-undang sebagai satusatunya sumber hukum, memisahkan undangundang dari ide-ide tentang moralitas dan nilainilai keadilan. Pokok-pokok pikiran kebangkitan kembali hukum alam mengajarkan bahwa moralitas (nilai-nilai keadilan dan kebenaran) merupakan unsur substantif, norma etis serta norma evaluatif terhadap undang-undang. J uga mengajarkan moralitas dan nilai-nilai keadilan merupakan aspek substansial dari undang-undang. Undang-undang yang tidak bersubstansikan moralitas dan nilai-nilai keadilan tidak layak dinamakan hukum. Hukum yang sungguh-sungguh merupakan hukum adalah hukum yang merupakan perwujudan nilai-nilai keadilan dan ditujukan untuk mencapai keadilan.

Reeksaminasi terhadap asas legalitas menunjukkan beberapa hal. Pertama, asas legalitas mempunyai daya jangkau dan ruang lingkup yang lebih sempit dibandingkan dengan gagasan nullum crimen sine poena. Asas legalitas hanya dapat digunakan untuk menuntut mala prohibita, sedang gagasan nullum crimen sine poena dapat digunakan untuk menuntut mala prohibita dan crimina extra ordinaria. Kedua, asas legalitas hanya menghasilkan ketidakseimbangan perlindungan hak yang diberikan kepada pelaku dan korban dan/atau masyarakat. Ketiga, asas legalitas memisahkan hukum dan moral serta nilai-nilai keadilan, padahal moral dan nilai-nilai keadilan merupakan aspek substansial dari hukum.

\section{Rumusan Asas Alternatif Sebagai Dasar Pemi- danaan Terhadap Perbuatan Pidana}

Berdasarkan hasil reeksaminasi, perlu dirumuskan asas alternatif yang lebih komprehensif dibandingkan dengan asas legalitas. Dalam hal ini, perlu dikemukakan dan dikembangkan gagasan tentang patut dipidananya kejahatan/perbuatan pidana, dengan rumusan setiap kejahatan/ perbuatan pidana harus dipidana jika bertentangan dengan hukum pidana, atau dapat juga dengan rumusan nullum crimen (delictum) nulla poena sine praevea ius poenali (tiada kejahatan/perbuatan pidana, tiada pidana, tanpa hukum pidana terlebih dahulu).

Berdasarkan rumusan gagasan tersebut, maka sumber hukum pidana adalah hukum tertulis yakni undang-undang pidana dan hukum tidak tertulis yang meliputi hukum kebiasaan (termasuk hukum pidana adat) serta prinsipprinsip hukum umum yang diakui oleh bangsabangsa beradab atau masyarakat bangsa-bangsa (general principles of law recognized by civilized nation/community of nations). Dengan sumber hukum yang seperti ini, akan mampu didayagunakan untuk menuntut mala prohibita maupun crimina ex-tra ordinaria'

\section{Penutup \\ Simpulan}

Ada beberapa simpulan yang dapat diberikan berkaitan dengan permasalahan yang telah dibahas. Pertama, Kritik Ideologis sangat perlu dilakukan terhadap dasar kefilsafatan asas legalitas, karena asas legalitas mempunyai kelemahan landasan ontologis dan aksiologisnya. Kelemahan landasan ontologis asas legalitas, karena substansi dasar asas legalitas hanya berupa undang-undang pidana dan mala prohibita. Kelemahan landasan ontologis dan aksiologis asas legalitas mengakibatkan timbulnya berbagai ke- 
terbatasan asas legalitas. Kedua, konsekuensi logis dari kritik ideologis adalah perlu dilakukannya reeksaminasi (pengujian kembali) terhadap asas legalitas dengan menggunakan beberapa kerangka teoritis sebagai pisau analisis, seperti: nullum crimen sine poena, serta The Revival of Natural Law. Reeksaminasi terhadap asas legalitas menunjukkan hal-hal sebagai berikut: (a) asas legalitas mempunyai daya jangkau dan ruang lingkup yang lebih sempit di-andingkan dengan gagasan nullum crimen sime poena. asas legalitas hanya dapat digunakan untuk menuntut mala prohibita, sedang nullum crimen sine poena dapat digunakan untuk menuntut mala prohibita maupun crimina extra ordinaria; (b) asas legalitas hanya menghasilkan ketidakseimbangan perlindungan hak yang diberikan kepada pelaku dan korban dan/atau masyarakat; dan (c) asas legalitas memisahkan hukum dan moral serta nilai-nilai keadilan, padahal moral dan nilai-nilai keadilan merupakan aspek substansial dari hukum. Ketiga, Berdasarkan hasil reeksaminasi, perlu dirumuskan asas alternatif yang lebih komprehensif sebagai dasar pemidanaan terhadap kejahatan (perbuatan pi-dana). Untuk itu, perlu dikemukakan dan dikembangkan rumusan asas lain yang lebih komprehensif yaitu: harus dipidananya kejahatan (perbuatan pidana), dengan rumusan setiap kejahatan (perbuatan pidana) harus dipidana jika bertentangan dengan hukum pidana atau dapat juga dengan rumusan nullum crimen (delictum) nulla poena sine praevea ius poenali (tiada kejahatan/ perbuatan pidana, tiada pidana, tanpa hukum pidana terlebih dahulu). Rumusan tersebut diharapkan dapat didayagunakan un-tuk menuntut mala prohibita maupun crimina extra ordinaria. Dengan dituntutnya criminal extra ordinaria, maka gagasan ini melakukan fungsi perlindungan kepada korban dan/atau masyarakat. Konsekuensi logis dari rumusan tersebut, sumber hukum pidana adalah hukum tertulis (undang-undang pidana) dan hukum tidak tertulis yang meliputi hukum kebiasaan (termasuk hukum pidana adat) serta prinsip-prinsip hukum umum yang diakui oleh bangsa-bangsa beradab atau masyarakat bangsa-bangsa.

\section{Saran}

Sebagai akhir dari tulisan ini, perlu disampaikan beberapa saran. Pertama, Perlu adanya kajian ulang terhadap rumusan Pasal 1 RUU-KUHP, terutama terhadap konsep tentang asas legalitas formal dan asas legalitas materill yang menimbulkan makna berlebihan pada konsep asas legalitas formal, serta kontradiksi terminologi (contradictio in terminis/terminological contradiction) dan kontradiksi konseptual (conceptual contradiction) pada konsep asas legalitas materiil. Konsep asas legalitas formal merupakan konsep yang berlebihan, karena dalam asas legalitas sudah terkandung makna formal tersebut. sedang konsep asas legalitas materiil telah menimbulkan kontradiksi terminologi, karena tidak mungkin memateriilkan konsep formal, atau sebaliknya memformalkan konsep materiil. Konsep asas legalitas materiil juga menimbulkan kontradiksi secara konseptual (conceptual contradiction), karena dalam konsep asas legalitas hanya berkaitan dengan hukum tertulis, sedang pada konsep asas legalitas materiil hanya berkaitan dengan hukum tidak tertulis. Unsur hukum tidak tertulis inilah yang secara konseptual bertentangan dengan makna asas legalitas yang hanya mengenal hukum tertulis; dan kedua, pembaharuan undangundang pidana di Indonesia harus didahului dengan kritik ideologis dan reeksaminasi terhadap asas-asas hukum tertentu, jika asas tersebut hendak dijadikan sebagai dasar pembaharuan.

\section{Daftar Pustaka}

Barry, Norman. “Dworkin's Unbounded Legalism, Ideas on Liberty". Vol. 52 November 2002. Irvington-Hudson;

Bromberg, Howard. "The Philosophy of Positive Law: Foundations of J urisprudence" The Review of Metaphysics, Vol 60. Maret 2007. Washington;

Fitriati. "Eksistensi Peradilan Pidana dalam Penegakan Hukum di Indonesia". J urnal Hukum, Vol. 1. No. 6. Padang: FH Universitas Taman Siswa;

Johnson, Paul. "Do We Need a Legal Philosophy? If so, what should it be?". The Spectator, Vol. 284. Jan 29. 2006. London; 
Ketua Mahkamah Agung RI. "Pedoman Perilaku Hakim". Varia Peradilan. No. 252 Oktober 2006. J akarta: Mahkamah Agung Rl;

Leskiewicz, Max. "The Normative Ontology of The Law - Peter Cane's Responsibility in Law and Morality". Law J ournal. Vol. 22. 2003. St. Lucia: University of Queensland;

Marmor, Andrei. "Legal Positivism: Still Descriptive and Morally Neutral". Legal Studies. Vol. 26. No. 4. 2006. England: Oxford University;

Moeljatno. 2000. Asas-Asas Hukum Pidana. Jakarta: Rineka Cipta;

Paulson, Litschewski Bonnie dan Stanley L Paulson. "Five Minutes of Legal Philosophy (1945)". Vol 26. No. 1. 2006;

Priel, Danny. "Trouble for Legal Positivism, Legal Theory". Sept 2006. Vol. 12. Cambridge;
Radbruch, Gustav. Oxford J ournal of Legal Studies. England: Oxford University;

Rahardjo, Satjipto. 2000. IImu Hukum. Bandung: Citra Aditya Bakti;

Russel. "Trial By Slogan: Natural Law anf Lex Iniusta Non Est Lex". Law and Philosophy. Vol. 19. 2000. Netherland: Kluwer Academic Publisher;

Schauer, Frederick. "Fuller's Internal Point of View" Law and Philosohy. Vol. 131994. Netherland: Kluwer Academic Publisher;

Theo dan Huijbers. 1982. Filsafat Hukum Dalam Lintasan Sejarah. Yogyakarta: Penerbit Kanisius;

Yusriyadi. "Paradigma Positivisme dan Implikasinya terhadap Penegakan Hukum di Indonesia". J urnal Hukum. Vol. 14. No. 3. April 2004. Semarang: FH Universitas Islam Sulta Agung. 